\title{
God met ons! \\ Die aanspraak op Goddelike steun in 'n \\ konfliksituasie volgens die Ou Testament
}

\author{
H R Balzer \\ Lutherse Teologiese Seminarie, Pretoria
}

\begin{abstract}
God with us! The claim of divine support in a situation of conflict, seen from an Old Testament perspective

Political discussions referring to Old Testament texts in order to claim divine support for one's views, and disqualify opposing opinions as being in conflict with the God of the Bible, are hermeneutically based on analogies between a revealed God, His representatives or laws, and ethical or political principles. A synchronic investigation of relevant Old Testament passages fully denies and opposes this hermeneutic approach, which is based on an isolation of principles or norms - with no regard to the only relevant actual relation to God himself. Any political identification with God or associated function must therefore be rejected as blasphemous from an Old Tes-tament perspective.
\end{abstract}

\section{INLEIDENDE OPMERKINGS}

Die kulturele en politieke geskiedenis van Suid-Afrika word tot op hede sterk beïnvloed deur die Christelike godsdiens. Die Christelike geloof kom vandag nog telkens ter sprake in die verwikkelinge in ons land. Dit geld veral in geval van konflik tussen verskillende instansies en groeperings. Feitlik geen groep of politieke party kan dit waag om sonder enige verwysing na die Christelike geloof of die Bybel hulle saak te beredeneer nie.

Die Christelike geloof en die Bybel word in 'n konfliksituasie heel dikwels op die toneel gebring met die vraag: 'aan wie se kant is God' (vgl bv The road to Damascus 1979:6)? Volgens Nürnberger (1985:26-27, 37) het selfs Maarten Luther 
mense daartoe opgeroep om 'onreg openlik aan die kaak (te) stel', maar eers te sorg 'dat jy God aan jou kant het'. So 'n stelling kan maklik tot die fatale misverstand lei as sou Luther in sy politieke etiek funksionele gebruik van God wou maak. Kunst (1979:399-401) het op oortuigende wyse oor hierdie saak gehandel.

Die pogings om die eie saak en posisie as Christelik te tipeer gaan dikwels gepaard met die godsdienstige diskwalifikasie van die opponente, met die klaarblyklike doel om hulle aanvaarbaarheid vir ander Christene te verlaag. Dit is trouens nog altyd gebruiklik dat (politieke) opponente in 'n Christelike samelewing mekaar as ketters brandmerk of selfs van afgodery en ateisme beskuldig. So 'n misbruik van die Bybel (naamlik om 'n opponent as ketter te verklaar) word gewoonlik weer as teenargument aangevoer tén die ketterverklaring.

In die moderne tyd het daar egter 'n nuwe dimensie bygekom: die misbruik van die Bybel word 'n legitieme gebruik. Die algemene waarheid van God se woord is nie meer die belangrikste nie, maar die funksionele gebruik daarvan is wel. Die Bybel en die Christelike geloof word onmiddellik aangewend om die eie standpunt te onderbou. Dit moet dien as stutwerk vir 'n ideologie of filosofie. Deist (1987:28) het met betrekking tot die Marxistiese teologie dit soos volg gestel: 'Marxist philosophy becomes the overriding doctrine or truth about reality...' Hierdie 'legitieme' gebruik van die Bybel lei tot 'n soort heilige oorlog wat in intensiteit dramaties kan toeneem. Die verwoestende gevolge van so 'n stryd is voor die hand liggend. Die Tweede Wêreldoorlog is 'n voorbeeld daarvan waar elke volk hulle in 'n mindere of meerdere mate op God beroep het. Duitse soldate het selfs die inskripsie Gott mit uns op hulle gordels gedra. Daar is natuurlik ook 'n beroep gedoen op ander waardes soos die demokrasie of die Rettung des Abendlandes. Die feit bly, dit is baie edeler om teen verteenwoordigers van 'die bose' te veg as om maar net teen ander mense te veg! 'n Moderne voorbeeld hiervan is die Kairosdokument wat sy politieke opponente as servants of the devil tipeer. Hierdie vyandmitologie is 'n nuwe soort satanologiese dualisme wat met terme soos system, people, oppressor en oppressed tot uitdrukking gebring word. Nolan (1988:84-86) gee ook indrukwekkende voorbeelde van hoe Christene mekaar toetakel. Die politieke opponent word onder andere as monster, demon, fetish en Antichrist getituleer. Elke ontmoeting of gesprek word daarmee by voorbaat feitlik onmoontlik gemaak; of dit vereis minstens baie pastorale toegewings aan die kant van die duiwel! Hierdie identifikasie van konkreet-menslike met abstrakte opponente word onder meer deur Gaybba (1985:182-184) gekritiseer. ('n Verdere bespreking van die probleem vind ons by Croatto 1981:30.) 


\section{HERMENEUTIESE ASPEKTE}

Uit die voorafgaande is dit duidelik dat die Bybel vir politieke konflikte diensbaar gemaak word. Veral uit verwysings na die Ou Testament (wat trouens nie net as pasifistiese dokument beskou kan word nie) kry 'n mens die indruk, dat God 'in diens staan' ten bate van een of ander politieke mikpunt. So 'n standpunt word vandag deur bykans al die kerke in Suid-Afrika gehuldig. Die ou konfessionele strydpunte het inderdaad voor 'n nuwe soort 'belydenis' gewyk. (Dit word soms ten onregte 'ekumenies' genoem, omdat dit in werklikheid aan politieke 'belydenisse' gebonde is.)

Deist (1987:28) het sulke ideologiese veronderstellings in die Bybelse hermeneutiek raak getipeer: 'Within this framework one can employ any exegetical method, as long as it is functional.' Ons onderskeiding van politieke en godsdienstige terreine is natuurlik vreemd aan die Ou Testament. Daaroor skryf Ravasi (1984:5): 'The Bible discloses two ideological threats: desacralizing politics and depoliticing religion.'

Die gevolg is dat enige konflik a priori 'n eksegetiese dimensie het wat onvermydelik direk of indirek aan elke teologiese navorsingsveld raak. Geen teoloog kan voorkom dat sy werk uiteindelik ook polities geïnterpreteer en in die politieke arena funksioneel aangewend word nie. Tog is dit nie die taak van die Ou-Testamentiese wetenskap om polities-ideologiese debatte te voer nie. Ravasi (1985:7) het die saak reg beoordeel toe hy geskryf het: 'Though intimately bound together, faith and politics are both autonomous. No political system can claim to be our ultimate salvation.' Maar in so verre as wat daar beroepe op die Ou Testament gedoen word, is die wetenskap van die eksegese dit nie net teenoor die ander teologiese vakgebiede nie, maar veral teenoor die Christelike kerke verskuldig om daardie interpretasies van die Ou Testament krities in oënskou te neem.

In die genoemde konflikte word daar ook steeds geskikte hermeneutiese metodes ontdek om die gesag van die Skrif vir eie doelstellings diensbaar te maak. Motlhabi (1987:6) het hierdie hermeneutiese vereiste vir elke teologie beklemtoon: 'Just as there can be no theology without an understanding of the word God, there can be no Liberation Theology without the Bible, which is the primary source of the Word of God.' Hiermee stem ons in beginsel saam.

Die hermeneutiese benaderings is egter uiteenlopend van aard. Die maklikste daarvan is natuurlik die beroep op feitelike Bybelse 'materiaal'. Die eenvoudige 'eklektiese' gebruik van enkele Bybelwoorde of kort eenhede uit die Ou Testament in nuwe en vreemde samehange of verbande is egter agterhaal. Sulke 'saamvoegings' het elke teologiese en filosofiese grondslag verloor, selfs in die geval van 'n meganiese teorie van verbale inspirasie (vgl Heyns 1978:18-24). Trouens, indien 
die gebruik van Bybelwoorde in die Bybel self nie in ag geneem word nie, lei dit onvermydelik tot misbruik van Bybelse gesag. Tereg sê Villa-Vicencio (1981:49): "The Bible is open and vulnerable to be appropriated for various causes and to be used for the enhancement of any political ideology.'

Dit is egter nie voldoende on eenvoudig vas te stel wat die Bybel aangaande bepaalde temas sê nie. Ons moet veral evalueer hoe die Bybel daardie inhoude aanbied. Sonder ' $n$ gebalanseerde oorweging van beide die materiële sowel as die metodologiese dimensie, sal geen verantwoordelike toepassing van Bybelse tekste moontlik wees nie. Hiermee sal die meeste teoloë ook in beginsel saamstem.

Die vraagstuk vereis 'n eenvoudige en algemene verstaanbare benadering met betrekking tot die Ou Testament: Hoe moet ons vasstel wie se kant God nou regtig kies, of wie veg aan die kant van God en wie doen dit nie? Is daar enige riglyne ten opsigte van inhoude en metodes? Die gevaar van 'n foutiewe metodologiese gebruik van sekere elemente in die Ou Testament word, soos reeds gesê, algemeen erken - hoofsaaklik natuurlik, om die verteenwoordiger van die 'ander kant' daarvoor te blameer.

Vir die do:l van hierdie artikel sluit dit per definitionem die bespreking van die konflikte tussen volgelinge van verskillende godsdienste uit, want dat God wel sy eie gesag teenoor ander gode handhaaf, kan as vanselfsprekend veronderstel word. Ons bespreking handel dus nie oor contra gentiles nie, maar eerder oor Deus contra deo! Om hierdie vraagstuk te kan bespreek moet ons in die eerste plek die hermeneutiese verbintenisse nagaan wat telkens tussen Bybelse uitsprake aan die een kant en politieke standpunte aan die ander kant gelê word.

Ten eerste word dikwels (in bykans elke dogmatiese ontwerp) 'n analogie tussen God se 'eienskappe' of goddelike attribute en die eie politieke standpunt getrek. Die eie posisies kan gevolglik met dié van God vergelyk of selfs geïdentifiseer word. Die tertium comparationis word in so 'n geval meerendeels uit ons eie tyd afgelei. Hierdie eienskappe van God, soos byvoorbeeld 'regverdigheid' en verskillende simpatieë of antipatië van God soos hulle in die Bybel aangedui word, kan op 'n eklektiese en spekulatiewe manier maklik uit verskillende Ou-Testamentiese tekste afgelei word. Die belangrikste teoretiese grondslag vir hierdie metode is die teologiese beskouing wat berus op die kwalifikasie van die Bybel as Selbstoffenbarung van God. Dit veronderstel dat die Ou Testament inligting oor die wese en karakter van God wou bemiddel. Dit kan uiteindelik tot 'n Grieks-Platoniese begrip van God en sy 'wese' teruggevoer word, soos onder meer deur König (1975:2) opgemerk. Hierdie teoretiese vooronderstellings is eintlik onvermydelik, selfs indien 'n mens die klem op sogenaamde 'dinamiese' kwaliteite van God se dade plaas en die 'statiese' eienskappe gevolglik deur iets soos 'kontinuïteite' of 'betroubaarhede' 
vervang. Metodologies maak die onderskeid tussen God se 'wese' en sy 'dade' hier nie saak nie, want dit loop uiteindelik uit op 'n eenvoudige soort sillogisme wat soos volg daar uitsien: Die (geopenbaarde) God is goed en staan ongekwalifiseerd aan die kant van die 'goeie' (op watter wyse 'goed' ook al verstaan en gedefinieer word). Ons verteenwoordig of werk vir dieselfde 'goeie', gevolglik is ons aan die kant van God/is God aan ons kant.

Ons kan hierdie manier om outoriteit op grond van goddelike gesag te verkry, die analogie-metode noem, want dit berus op die vasstelling van analoë etiese kwaliteite tussen God en mens.

Hierdie patroon kan natuurlik in 'n hele aantal verskillende variasies aangebied word. Gewoonlik word dit nie op hierdie abstrakte manier beskryf nie, maar min of meer as vanselfsprekend veronderstel. 'n Belangrike variasie is die identifikasie van eie posisies, nie met God nie maar wel met dié van Bybelse karakters. Indrukwekkende voorbeelde vir totaal verskille identifikasies met die volk Israel is deur VillaVicencio (1981:48-52) saamgestel. Ongelukkig het hy later vir homself 'n definisie oor godsdienstige bevoorregting opgestel: 'To the extend, that Israel is poor, defeated and enslaved she is blessed in a special way by God' (Villa-Vicencio 1981: 57). Maar wat dan van die tye van Dawid, Salomo en die ander groot konings? Daardie sosiologiese definisie van die simpatie van God in haglike omstandighede stem eerder met 'n sekere erkenntnisleitendem Interesse as met die getuienis van die Ou Testament ooreen. Armoede is byvoorbeeld op sigself tog nie 'n godsdienstige kwaliteit nie! Behalwe Israel word ook profete of selfs Jesus Christus, wat min of meer geïmiteer moet word, as nastreefwaardige voorbeelde gebruik, omdat hulle glo God se 'siening' reflekteer.

Hierdie algemene analogie-model sluit logies in dat die opponente as vyandig teenoor God se kwaliteite getipeer word. Soms word aan hulle nog 'n kans vir berou toegestaan, soms word dit ook eo ipse uitgesluit. Dis meer 'n geval van styl, hoe die opponente op hulle knieë gedwing sal word: of hulle vernietig sal word (soos in die Duitse antisemitisme van 1933 tot 1945) en of hulle moet verander (wat klaarblyklik die konsep van The road to Damascus [1989] is).

Behalwe hierdie model vind ons in politieke argumente natuurlik ook die verwysing na wette of verwagtinge van God in die Ou Testament wat gehoorsaam moet word. Dit veronderstel nie noodwendig 'n Selbstoffenbarung van Deus ipse nie, maar wel 'n openbaring van sy 'wil' of 'plan'. Net soos in die geval van analogieë word daar abstraksies gemaak. 'n Goeie voorbeeld van so 'n abstraksie is dié van Mitmenschlichkeit wat deur Braun ontwikkel is, asook die verskillende genitief-teologieë (byvoorbeeld Theologie der Hoffnung van Moltmann). Hierin word God min of meer tot sekere beginsels gereduseer of God word selfs deur die beginsel vervang! 
Al hierdie metodologiese benaderings poog om God op 'n sistematiese wyse te beskryf. Afhangende van definisie kan 'n mens dan bepaal aan wie se kant God behoort te wees en wie Hy behoort te verwerp!

Natuurlik pas so 'n definisie byna volmaak in elke stryd. Die dwaling van hierdie metode is nie so deursigtig nie. So is byvoorbeeld gehoorsaamheid, teologies gefundeerde etiek in menslike verhoudings, loon en straf inderdaad OuTestamentiese onderwerpe, asook uitsprake oor verskillende kwaliteite wat aan God toegeken word, veral in teenstelling met die afgode. Trouens, God is in baie konflikte in die Ou Testament nie neutraal nie, maar kies kant èn beredeneer dit! Ek stem op hierdie punt saam met Ravasi (1984:5): 'A fideistic pan-spiritualism that absorbs politics into faith and ignores authentic human reality is ultimately not a biblical ideal.'

Aan die ander kant kry 'n mens met sulke algemene metodes klaarblyklik geen algemeen erkende oplossings van die genoemde probleme nie en moet daar eksegeties wel ewe swak gefundeerde alternatiewe in verband met 'n belangrike OuTestamentiese onderwerp toegelaat word. Om hierdie rede vra ons in hierdie artikel na die basis en toepasbaarheid van ons eie bekende hermeneutiese benaderings, wat daartoe gelei het dat die steun van die God van die Ou Testament in 'n stryd toegeëien word of aan 'n ander ontse word. Hoeveel van ons gewone metodes in die bepaling van die verbintenisse en analogië tussen Bybelse tekste en vandag se politieke konflikte is regtig eksplisiet en konkreet in die relevante Ou-Testamentiese tekste uitgespel of onmiskenbaar aanwesig? Waarop berus hierdie politieke aansprake wat gebaseer word op die Ou Testament? Is die klaarblyklike onmoontlikheid om die kant wat God kies in 'n politieke konflik, onmiskenbaar te bewys, die resultaat van die veelsoortigheid van Bybelse tekste, of bestaan hierdie indruk eerder vanweë sekere vooringenome houdings en verwagtinge wat ons self in 'n mindere of meerdere mate onbewus in die tekste indra?

Hierdie metodologiese grondslae vra in 'n sekere sin 'n negatiewe metodologiese benadering: Watter voorwaardes met betrekking tot die steun of opposisie van God se kant, kan regtig en positief in die tekste geverifieer word? Ons sal gevolglik moet probeer om die relevante tekste sonder sekere van die vooronderstellinge waarop die gewone interpretasie berus, onder die loep te neem. Dit geld veral met betrekking tot goddelike 'eienskappe', waarvan ons hipoteties moet afsien, want die tekste self noem dit in concreto net binne konkrete relasies tussen God en mense. Verder sal ons die hermeneutiese benadering, wat ons die analogie-model genoem het, nie sonder baie goeie redes kan veronderstel nie. Word dit eintlik in enige vorm in die Ou Testament self gebruik? Scriptura scripturam interpres! Sonder ' $n$ 'positiwistiese' benadering is geen gesagvolle Bybelse eksegese moontlik nie. 
Natuurlik is dit vandag geen probleem om die 'teenstrydighede' ten opsigte van die politieke kwaliteite van God binne die Ou Testament histories-krities op te los nie. Ons kan wel sake sistematiseer wat vanweë verskillende historiese omstandighede en herkomste nie bymekaar hoort nie. Dit is inherent 'n induktiewe benadering. Gevolglik is die bogenoemde politieke funksionele gebruik van die Ou Testament a priori nie moontlik nie. Ons kan in so 'n geval hoogstens een teks teen ' $n$ ander afspeel of verskillende historiese 'tipes' of 'stadia' van die politieke kwaliteite van God definieer. Sodoende word die probleem net verskuif maar nie in beginsel verander nie. Maar dié kritiese oordeel veronderstel aan die ander kant logies alreeds 'n 'sinchroniese' begrip van Bybelse inhoude, waaroor ons met betrekking tot hierdie onderwerp glad nie beskik nie! Daar bestaan inderdaad verskillende Gottesvorstellungen tussen die verskillende Bybelse boeke en verskillende skrywers. Maar voordat ons veronderstel dat in hierdie (en ander) opsigte die redakteurs van die Ou Testament almal nalatig was, moet ons seker maak dat ons self nie mislei word deur ons eie hermeneutiese perspektief wat die indruk van hierdie teenstrydighede veroorsaak nie. Elke histories-kritiese metode berus uiteindelik op ons eie verwagtinge van 'n soort homogene teks wat nie noodwendig met dié van die skrywer(s) ooreenstem nie.

\section{METODOLOGIESE OORWEGINGS}

Die gestelde probleem vereis 'n (hipoteties!) sinchroniese benadering om in die historiese hermeneutiese sirkel in te tree. Ons eie vráastuk vorm die vertrekpunt en is eerder sistematies as histories van aard. Ons gaan probeer om teologies na te dink oor 'n bepaalde en abstrakte onderwerp wat buite die teks, naamlik in die moderne teologiese gesprek, ontwikkel het. Dit is nie van soveel belang van watter materiaal of Vorlage die beroemde 'laaste redakteur' of skrywer gebruik gemaak het nie. 'Agter' die gegewe teks soek ons niks nie. Die fondament waarop elke histories-kritiese oordeel berus, is uiteindelik die hermeneutiese benadering wat ook die relevante kategorieë bepaal! Omdat ons hier hipoteties 'n nuwe benadering probeer gebruik, moet ons die resultate van histories-kritiese kommentare voorlopig ignoreer. Daarmee is die diachroniese dimensie nie eo ipse uitgesluit nie, en is die reg (en in sekere gevalle selfs noodwendigheid) om met ander eksegetiese onderwerpe vice versa diachronies te begin, nie bestry nie.

Met die oog op die onderwerp sal dié tekste in die Ou Testament ondersoek word waar die steun van God in 'n situasie van politieke konflik toegeëien of ontsê word. Die bedoeling is vanselfsprekend nie om volledige kommentaar oor die tekste te lewer nie. 
Om beter te kan vergelyk, sal elke teks in dieselfde volgorde bespreek word wat die volgende aspekte betref:

- Na die identifikasie van 'n bepaalde teks word die posisie en redenasie van dié party telkens beskryf wat volgens die outeur uiteindelik verwerp word. Is 'n mens aan God se kant of nie, en hoe kan hy dit weet of nie weet nie?

* Daarna word in teenstelling met die 'verkeerde' party die aanspraak op God se steun, wat die voorkeur van die Bybelse skrywer geniet, bespreek. (In albei gevalle word, indien kontekstueel aangetoon, die kritiek vanuit albei perspektiewe teen die aanspraak van die opponente ingesluit.)

- Die Bybelse gegewens word dan ten slotte bespreek binne die raamwerk van ons probleemstelling en teen die agtergrond van die gekose metodologiese uitgangspunte.

Ter wille van vereenvoudiging sal alle tekste wat ondersoek word, in drie kategorieë of tipes saamgevat word. Ons neem bekende Ou-Testamentiese onderwerpe as uitgangspunte wat soos Gattungen gebruik kan word. (Elke definisie, ook van gevestigde erkende Gattungen, is eindelik niks anders nie as die resultaat van bepaalde hermeneutiese perspektiewe wat telkens nie van die Ou Testament self nie, maar van die uitgangspunt van die navorser afkomstig is.) Dit sal egter nie die resultate van ons ondersoek beïnvloed nie maar is net ter wille van duidelikheid en om herhaling te voorkom. In die eerste plek bespreek ons die stryd om God se steun vir aansprake op politieke leierskap en voorregte, wat in die Ou Nabye Ooste altyd priesterlike aspekte ingesluit het. In die tweede plek bespreek ons die vraag na die teologiese basis van kultiese of profetiese godsdienstige handelinge, soos dit onder meer in die sogenaamde Kultpolemik of die onderskeiding tussen sogenaamde ware en valse profete tot uitdrukking kom. In die derde plek word die onderwerp van die betroubaarheid van die steun deur God vanweë sy nasionale of historiese verbintenisse (byvoorbeeld in die teologie van die sogenaamde Deuteronomistiese geskiedswerk) bespreek. Met hierdie voorlopige groepering as uitgangspunt word die gevalle soos dit in die Bybel voorkom, nagegaan.

\section{DIE STRYD OM GOD SE STEUN VIR POLITIEKE LEIERSKAP}

Ons eerste voorbeeld vir die stryd om die teologiese legitimasie van leierskap, is die verhaal van Korag se opstand teen die alleenheerskappy van Moses volgens Numeri 16. Noth (1977:107-108) wys daarop dat behalwe Korag in sekere Vorlagen ook Datan en Abiram (vers 12-15) as opstandige leiers figureer. Ons beskou hulle hier 
net as verteenwoordigers van die rebellie teen Moses en/of Aăron.

Dié teks noem goeie en verstaanbare redes vir die protes teen Moses en vir hulle eise om 'n aandeel in die politieke mag: Volgens vers 3 is die heiligheid 'n kenmerk van die hele gemeente, sodat Moses en Aäron geen aanspraak vir hulle eie voorregte op grond daarvan kan maak nie. Hierby moet die ernstige politieke mislukkings van Moses (vers 13-14) onthou word; ja, selfs die besware oor tirannie (vers 14). Dit is opvallend dat Korag die meerderheid van die volk aan sy kant het (vgl vers $2,19,41$ ). Hulle protesteer ook nadat die rebelle omgekom het (vers 41-46). Tog berus die aanspraak van Korag uiteindelik op eie belange waaraan hy God diensbaar wil maak.

Wat is nou aan die ander kant Moses en Aăron se redes vir hulle godsdienstige aansprake? Geen enkele rede word in die teks genoem nie! In plaas daarvan wys hulle op die inisiatief van God en hoe hulle in 'n spesiale verhouding met Hom staan en wat $\mathrm{Hy}$ aan hulle geskenk het as praedestinatio (vers 5). En volgens Moses (vers 9-11) is dit ook die enigste grond vir die (beperkte) politieke en kultiese gesag wat Korag en sy mense self geniet het!

Die teologies gefundeerde aansprake van Korag sou deur selfstandige politieke aksie (die opstand) bereik kon word. Moses se gesag hang aan die ander kant van die ingrype van God af, maar hy moet daarvoor bid. God moet Moses se reg deur 'n sigbare teken, naamlik die vernietiging van die rebelle bevestig (vers 28-35). In plaas van 'n logiese uiteensetting van redes vind ons 'n spesiale verhouding met God.

In breër teologiese verband dui ons teks daarop dat daar 'n skerp waarskuwing uitgespreek word teen enige iemand wat God vir sy eie politieke ideale wil misbruik (al is die ideale ook teologies gefundeer!). Terwyl Korag God in werklikheid in sy diens neem, staan Moses omgekeerd in diens van God. Die goddelike steun vir Moses voldoen beslis nie aan die vereistes wat 'n mens van enige teologiese beredenering of uiteensetting sou verwag nie. Dit vorm egter die grondslag waarop elke aanspraak moet berus. Anders moet die Godsoordeel (vers 28-30) wat Moses waag as uiters ongewoon en gevaarlik beskou word.

Net soos Numeri 16 hang ook Dawid se opstand teen Saul volgens 1 Samuel 18 tot 1 Samuel 31 van die verhouding met God af. (Bewerings dat God volgens die hele Bybel in beginsel meer aan die kant van die establishment of die revolusie staan, berus klaarblyklik op die aanwending van valse kategorieë. Korag sterf, Dawid oorwin - waar is nou die politiese 'regverdigheid' van God?) Albei opponente is deur die Here gesalf. Die ondergang van Saul en die vooruitgang van Dawid word primêr daaraan toegeskryf dat God self sy keuse verander het (byvoorbeeld 1 Sam 15:11; 16:1; 28:6, 15-18; volgens 1 Sam 24:21 word Dawid selfs deur 
Saul as koning geproklameer). Die sekerheid van steun of verwerping word nie uit spesiale politieke of etiese kwaliteite afgelei nie. Inteendeel, selfs die 'foute' van Saul, veroorsaak deur ' $n$ 'bose gees', staan op God se rekening (vgl 1 Sam 18:10; 19:9). Daar is trouens, ten spyte van die kultiese foute van Saul, wat uitsluitlik betrekking het op sy (kultiese) verhouding met God, volgens 1 Samuel 15:9, 10 geen rede vir die aanspraak 'God met ons!' nie. Dawid laat die inisiatief aan God oor, anders sou die hele storie slegs as die ongeregverdigde opstand van 'n verraaier en rower teen die regmatige koning verstaan kan word. Uiteindelik het juis die eie (teologiese) gevolgtrekkings van Saul volgens 1 Samuel 15:20 tot die verandering van sy verhouding met God gelei.

Volgens dié teks kan ons gevolglik sê dat nie teologiese of etiese beginsels nie maar slegs die verhouding in actu, die steun van God beslis.

In die voortsetting van die stryd om Dawid se koningskap teen Is-Boset, die seun van Saul, is die grondslag van die Bybel se motivering dieselfde: In 2 Samuel 3:9 word die verraad van Abner teen Is-Boset in sy oorlog teen Dawid deur God se eed van steun aan Dawid gemotiveer, maar omgekeerd word God se hulp geensins van iets anders afgelei nie.

Net so berus die oorwinning teen die rebellie van Absalom uitsluitlik op Dawid se verhouding met God en wel soos dit deur God self bepaal is ( 2 Sam 15:25). Hierdie fundamentele verhouding lei volgens 2 Samuel 16:8-12 selfs tot die geduldige aanhoor van 'n gevaarlike vloek in die naam van die Here (en miskien nie sonder goeie historiese rede nie).

Selfs die spioen Gusai ken teenoor die rebellie van Absalom geen ander rede vir die koningskap as die saak van die verkiesing deur God en die volk (2 Sam 16:8) nie: Die politieke stryd is inderdaad die stryd om God se steun, onafhanklik van enige ideologiese of etiese redes. Soos Saul word ook Absalom uiteindelik deur God self vernietig (2 Sam 18:12; 19:1-9).

In die stryd tussen Adonia en Salomo spreek die regsorde duidelik ten gunste van Adonia (1 Kon 2:15, 22). Verder is dit hy wat die steun van die volk geniet. Desnieteenstaande vind die outeur dit voldoende om slegs een rede ten gunste van die reg van Salomo teenoor Adonia te noem, naamlik die steun van God (1 Kon $2: 15,24)$. Weer eens word God se steun en verwerping nie uit enige etiese of ideologiese beginsel afgelei nie, maar is sy vrye keuse die primêre basis vir die 'kant' wat Hy kies. 


\section{PROFETIESE EN KULTIESE HANDELING EN DIE 'KANT' WAT GOD KIES}

Hierdie onderwerp word bykans paradigmaties in Numeri 22-24 beskryf waar Balak poog om God deur middel van die profeet Bileam aan sy doel diensbaar te maak. Die teks mag selfs as 'n soort opsomming van belangrike elemente van die sogenaamde profetiese teologie (wat in die moderne teologie van bevryding 'n dominante rol speel, vgl Kairos 1986:23-27) verstaan word.

Balak en Bileam stem saam oor die belangrikheid van die gesag van God en sy profeet (Num 22:6). Aan wie se kant staan God in die verdediging van Moab teen die agressiewe en imperialistiese Israelitiese aanvalle? Balak het in daardie situasie inderdaad goeie rede om Bileam (teen goeie betaling) te huur (Num 22:17, 18, 37b) en alles in sy vermoë te doen om homself van God se hulp te verseker, byvoorbeeld deur onder meer die skepping van die regte kultiese en topografiese omstandighede (Num 23:1, 2, 4, 14, 15, 29, 30). Bileam het slegs een rede om dit te weier: die primêre verhouding van God tot Israel, tot homself en tot Moab laat geen vervloeking toe nie, maar alleen seën vir Israel (Num 22:12, 35; 23:12, 26). God word nòg deur Balak nòg deur Bileam in diens geneem, maar Hy neem wel Bileam as sy profeet in diens. Die 'kant' wat God hier kies, is weer eens nie teologies of ideologies van enige beginsel of goddelike 'eienskappe' afgelei of afhanklik nie.

'n Verdere groep tekste, die sogenaamde profetiese Kultpolemik, is teen 'n ander soort Godsvertroue en geloof gerig: daarvolgens is die heil van God deur die praesentia Divina in die tempel teenwoordig en deur die kultus bemiddel. Dit is trouens maklik om dit te verstaan, want op dié wyse bewys Jahwe Hom inderdaad as 'n betroubare God. Maar dit lei ook maklik tot 'n soort 'aanstelling' van God vir menslike doelwitte. (Dit is teologies nie voldoende om dié tekste slegs as 'n soort vaticina ex eventu na die vernietiging van die tempel in die jaar 587 te beskou nie.)

Volgens Jeremia 7:1-15 verseker die opponente van Jeremia hulleself van God se steun met verwysing na die tempel en die kultus (Jer 7:4,10). Vers 10 dui egter aan dat hulle tempel en etiek nie van mekaar skei nie maar die tempel feitlik gebruik om vir etiese, sosiale en godsdienstige foute (vers 9) te kompenseer. Teen hierdie siening van 'n gewaarborgde kulties-historiese kontinuilteit van die heil in die tempel tree Jeremia sterk op en verwys na die kontinuïteit (!) van die deurgaans voorwaardelike karakter van die verhouding met God, waarvan die verbreking selfs tot die verwoesting van die beroemde heiligdom in Silo gelei het (vers 12-15). Deur middel van die Botenspruchformel (vers 3 ) verwys hy na God as die primêre basis van elke relasie.

Vir ons teologiese vraagstuk kan ons daaraan vashou dat die teks wel die integrasie van die etiek in die verhouding met God beklemtoon. Tog word God geensins as 'n funksie van die etiek in diens geneem nie! Inteendeel, die indiensneming 
van God (wat omgekeerd die mense in sy diens wil neem) moet as die godsdienstige fout par excellence beskou word.

Die mense wat volgens Jesaja 1:11-17 deur God veroordeel word, kan wêl op belangrike godsdienstige rituele 'n beroep doen: offers en gebede is rite uitgevoer (vers 11-15). Die ware verhouding met God het egter betrekking op die hele lewe, veral op die etiese aspekte daarvan. Hierdie mense het die verhouding met God sélf bepaal. Teen hierdie omkering van die relasie is die profetiese protes gerig. (Ook die gelyksoortige motief in Amos 5:22-25 is nie net teen 'n swak moraal nie, maar veral die eiematige bepaling van die verhouding met God gerig).

Volgens Jeremia 28 het die profeet Gananja met 'n beroep op God in die Botenspruchformel die bevryding van die opperheerskappy deur die Babiloniese vyande voorspel. Jeremia het saamgestem (vers 6), en albei het die profesie deur die Zeichenhandlung (vers 10-11) bekragtig. Hulle was albei in ooreenstemming met die politieke denke van die tyd en die geloof in Jahwe die verlosser. Jeremia waarsku egter dat 'n profesie van heil alleen op die regte verhouding van 'n profeet met God kan berus (vers 9-10). Dit is anders in die geval van die voorspelling van onheil. Hier stem die profesie nie met die eie voorstellings en wense ooreen nie, en is die gevaar dat die profesie vir eie belang aangewend kan word, nie so groot nie. Cui bono? Dié oorweging laat Jeremia onraad merk. In vers 12-14 word 'n ware profesie van Jahwe (vgl weer eens die Botenspruchformel, vers 13) alleen op die verhouding met God gegrond: die valse profete is nie 'gestuur' nie (vers 15). Hierdie feit, bekragtig deur die ondergang van Gananja (vers 16-17), is al wat tel! Dít, en nie die inhoud van die voorspelling as sodanig nie, makk die woorde van Gananja 'n leuen. Van der Woude (1973:13-16) het tereg aangetoon dat die verskil tussen 'ware' en 'valse' profete nie aan die persoon van die profeet gebonde is nie (onder meer met verwysing na $1 \mathrm{Kon} 13$ ). Hy meen dat dit verstandig is om die inhoud van die profetiese woorde as maatstaf te beskou, maar hou daaraan vas dat tot dusver nie een enkele kriterium ten volle geldig is nie: 'Daarmede worden wij gedrongen tot de conclusie dat een aprioristische maatstaf ter verificatie van een in naam van Jahwe gesproken woord inderdaad niet bestaan.' Maar Van der Woude onderskei tussen God, die profeet en die volk en hanteer elkeen van dié min of meer onafhanklik van die verhouding waarin die een tot die ander staan. In 'n beskouing wat funksioneer binne die raamwerk van reële verhoudinge, sal so 'n probleem egter nie bestaan nie.

Ook die stryd tussen ware en valse profete in Esegiël 13 beklemtoon die ooreenkoms van valse profete se woorde met hulle 'eie gedagte' (vers $2,3,17$ ). Hulle verstaan God as die God van heil (vers 10 en 15; vgl Jer 6:14; 8:11), en hulleself gevolglik as gesante van God (Eseg 10:6b). Die basiese kritiek teen die valse 
profete is weer eens die kritiek van 'n verkeerde verhouding met God: hulle is 'nie gestuur nie'. Daarom kan hulle woorde 'leuens' genoem word (vers 6, 8, 9, 19). Die uiteindelike oordeel spreek God self uit (vers 10-16).

Die ware profeet is nie 'vasgevang' deur die boodskap of sy intensies nie maar deur die verhouding met God, soos dit in die Botenspruchformel (vgl Eseg 13:8 en 22:28) en die goddelike bevel tot uitdrukking kom (Eseg 13:17). Die doel van die goddelike aktiwiteit is weer die tot stand bring van die regte verhouding met God (vers $14 b, 23 b$ ).

Die polemiek in Jeremia 23:9-40 vlek die posisie van die valse profete oop: Hulle woorde stem ooreen met hulle eie gedagtes (vers 16, 17, 25, 26b). (Omdat die 'hart' in Hebreeus veral 'n 'rasionele' dimensie simboliseer, sluit die vers ideologiese en ander redes nie eksplisiet uit nie.) Die valse profete kan hulle op drome beroep (vers 25). Die bestryding van die beroep word weer eens deur die verhouding met God bepaal: die valse profete is 'nie gestuur nie' (vers 21,32 ). 'n Ware profesie sal aan die ander kant bekering tot gevolg hê (vers 22). God is ook ver weg' (vers 23). Dit beteken Hy is outonoom en soewerein sodat 'n mens nooit in staat sal wees om Hom vir jou eie doelwitte te gebruik nie. Elke bewering oor God, juis dié wat gemaak word as grondslag vir verdere gevolgtrekkings, word daarmee tot 'n leuen oopgevlek (vers 17, 32; $\mathrm{m}$ b t die volk vgl vers 26-27). Die verhouding met God, gestig deur die 'woord' of 'daad' (vers 9, 11, 28, 29) omvat baie meer as net 'n funksie van kommunikasie. Hierdie feit is deur die valse profete geïgnoreer. Hulle begin in plaas daarvan by die mense. Daarby het hulle God as ' $t$ ware ingespan om hulle etiese foute goed te maak (vers $11,14,22$ ).

Al hierdie tekste kan beskou word as 'n waarskuwing teen die indiensneming van God vir enige 'kant' in 'n stryd.

\section{DIE 'KANT' WAT GOD KIES EN DIE GESKIEDENIS VAN DIE UITVER- KORE VOLK}

Ten slotte kan Godsvertroue ook berus op die kontinuïteit van die nasionale geskiedenis van die uitverkore volk, met ander woorde op 'n gewaarborgde politieke Godsverhouding. Die waarborg van God se steun deur die kontinuïteit van die nasionale geskiedenis word veral in die sogenoemde Deuteronomistiese interpretasie van die geskiedenis gekritiseer.

Dit is die geval in I Konings 22 (vgl 2 Kron 18), wat ook die vraagstuk van God se 'kant' in 'n stryd tussen profete, behandel. Die oorweldigende meerderheid wat bestaan uit 400 profete ( 1 Kon 22:6, 12) kan tereg van Miga verwag dat hy by hulle moet aansluit om die heil van Jahwe aan die koning bekend te maak (vers 13,15 ). 
Hulle praat nie uit hulle eie nie, maar is inderdaad deur 'n gees geïnspireer (vers 22). Miga volg hulle, totdat die koning self aandring op die onafhanklikheid van die profetiese woord 'in die naam van Jahwe'. Daarop reageer Miga met iets wat onmoontlik klink: God het alreeds die kant van die vyande gekies! (Dit word semanties ook in vers 23 saamgevat; vgl Balzer 1987:102-104.) Die gees is nie meer dié van heil nie, en daarom moet hy nou, nadat die koning op ware profesie aangedring het, onheil profeteer. Hierdie uitspraak word egter nie beredeneer nie, sodat die betroubaarheid van Miga volgens vers 25 van die bevestiging deur historiese ontwikkelinge afhang.

Die teks laat geen moontlikheid oop dat God 'in diens' geneem word nie. God stem met geen sisteem of 'kant' ooreen nie, sodat niemand op Hom aanspraak kan maak nie. Maar Hy neem wel vice versa elke betrokke mens (soms onbewus) in sy diens. Die Deus ipse bly 'n Deus absconditus, soos Terrien (1078:470-483) dit vanuit verskillende perspektiewe beredeneer het.

Esegiël 33:24, waarvolgens die inwoners van Jerusalem hulle op die historiese kontinuïteit van die belofte aan Abraham beroep, wys dit as 'n onafhanklike beroepsbasis van die hand. In hierdie verband word verder die val van Jerusalem in die raamwerk van die godsverhouding geïnterpreteer (vers 25 ).

Die bekende verhaal in Amos 7:10-17 beklemtoon die verhouding van God met die profeet sonder om die inhoud van sy (volgens vers $10 \mathrm{~b}$ moontlik noodlottige) uitspraak op die voorgrond te stel.

Volgens Miga 2:6-11 berus die optimisme van die opponente van die profeet op die vertroue op God se goedheid (vers 6-7). Die profeet kritiseer hierdie houding met verwysing na die verbreking van die godsverhouding deur die mens self. Hier word etiek en moraal wel as deel van die godsdienstige plig vereis, maar nie in omgekeerde orde godsdiens as etiese plig nie.

\section{GEVOLGTREKKING}

Ten slotte kan ons nou die Bybelse gegewens kortliks in die lig van die dogmatiese vraagstuk bespreek.

Die poging om God se 'kant' in 'n stryd te identifiseer en om op grond daarvan op sy steun ' $n$ beroep te doen, verskyn in verskillende tekste in die Ou Testament. Dieselfde tekste verhoed ons egter telkens om enige redes, wat staan nog beginsels op te stel waardeur ons God en sy dade sou kon beperk. Die verhouding met God, waarvan alles inderdaad afhang, is steeds primèr! Dit is die taak van die mens om dit so te aanvaar en om die eie lewe en dade daarby aan te pas. Elke poging om God op grond van enige voorstellings wat ons van Hom het, aan enige 'kant' te 
plaas, word in die Ou Testament nie versigtig vermy nie, dit word summier verwerp. Gevolglik berus die saak van God se 'kant' daarop dat ons in 'n verhouding met Hom staan en dat Hy ons in sy diens neem in plaas daarvan dat ons Hom gebruik.

Die ou en moderne manier om aanspraak op God se steun in 'n politieke of ideologiese stryd te maak, behoort gevolglik as godslastering veroordeel te word, want die ware karakter van die verhouding tussen God en mens word daarmee verdraai. Die verhouding tussen God en mens is onafhanklik van die aard en inhoud van die aanspraak. Dit sluit die etiese kwaliteite van die aansprake maak, in. Die analogie-model is foutief vanweë die eiematige identifikasie van God met menslike begrippe en intensies. Om God nog as die Ganz Andere selfs op hierdie manier te probeer beperk, beteken om 'n menslike afgod te skep. Niemand kan teenoor Christelike opponente met 'n beroep op die Ou Testament die aanspraak maak dat God aan sy kant is of teen die opponente gekant is nie, want God laat nie toe dat enige 'beginsel' Hom inperk nie. Geen ideologiese of etiese 'beeld' pas uiteindelik op Hom nie. Om dít in te sien en sodoende die maiestas Dei te respekteer, is die enigste korrekte menslike houding.

Die ideologiese en politieke diskussie binne die Christelike kerke is beslis nodig en kan ook vrugbaar wees. Ons moet egter onthou dat ons volgens menslike vermoëns met mekaar debatteer - ook en veral met die Bybel in die hand. Dit is nie moontlik om enige beginsels of ideologieë oor God of sy 'openbaring' af te lei nie. Die Ou Testament aanvaar in elk geval nie een van daardie abstraksies nie.

\section{Literatuurverwysings}

Balzer, H R 1987. Die Umwandlung göttlicher und menschlicher Verhältnisse: Zur Semantik der Verbindung des pi. der Wurzel dbr mit der Präposition cl im Alten Testament. Marburg: Diss. theol.

Biblia Hebraica Stuttgartensia 1967/77. Stuttgart: Deutsche Bibelgesellschaft.

Boesak, A 1976. Farewell to innocence: A social-ethical study of black theology and black power. Johannesburg: Ravan.

Croatto, J S 1981. Exodus: A hermeneutics of freedom. New York: Maryknoll. (Orbis.)

Deist, F E 1987. How does a Marxist read the Bible? in De Villiers, P G R (ed), Liberation Theology and the Bible, 15-30. Pretoria: UNISA.

Gaybba, B 1985. The Kairos document: A response. Grace and truth 6, 181-193.

Heyns, J A 1978. Dogmatiek. Pretoria: N G Kerkboekhandel.

Kasper, W 1986. Die Theologie der Befreiung aus europäischer Perspektive, in Metz, J B (Hrsg), Die Theologie der Befreiung: Hoffnung oder Gefahr für die 
Kirche?, 77-98. Düsseldorf: Patmos.

König, A 1975. Hier is Ek! Oor God. Gelowig Nagedink, deel 1. Pretoria: N G Kerkboekhandel.

Kunst, H 1979. Evangelischer Glaube und politische Verantwortung. Martin Luther als politischer Berater seiner Landesherm und seine Teilnahme an den Fragen des öffentlichen Lebens. Stuttgart: Evangelisches Verlagswerk.

Motlhabi, M B G 1987. Liberation Theology: An introduction, in de Villiers, P G R (ed), Liberation Theology and the Bible, 1-14. Pretoria: UNISA.

Noth, M 1977. Das vierte Buch Mose Numeri. Göttingen: Vandenhoek.

Nolan, A 1988. God in South Africa: The challenge of the gospel. Cape Town: David Philip.

Nürnberger, K 1985. Maarten Luther se politieke etiek teen die agtergrond van sy teologiese benadering. Potchefstroom: Instituut vir Reformatoriese Studies.

Ravasi, G 1984. Old Testament political theology. ThD 31, 3-7.

Schrey, H P 1969. Entideologisierung als hermeneutisches Problem. Tubingen: Mohr. Terrien, S 1978. The elusive presence: Toward a new biblical theology. San Francisco: Harper \& Row.

The road to Damascus: Kairos and conversion 1989. Braamfontein: Skotaville.

Villa-Vicencio, C 1981. Israel: An image of captivity for contextual theology. Theologica Evangelica 14/2, 48-62.

Van der Woude, A S 1973. Ware en valse profetie in Israël, in Berkouwer, G C \& Van der Woude, A S, Wat is waarheid? Waarheid en verifikasie in Kerk en Theologie, 13-20. Kampen: Kok.

Zuurmond, $\mathrm{R}$ 1985. Challange to the church: The Kairos document and commentaries. Geneva: World Council of Churches. 